Selcuk Journal of Agriculture and Food Sciences

http://sjafs.selcuk.edu.tr/sjafs/index

Research Article
SJAFS

(2021) 35 (3), 194-201

e-ISSN: 2458-8377

DOI:10.15316/SJAFS.2021.248

\title{
Morphological and Physiological Effects of Drought Stress on Some Strawberry Cultivars
}

iD Mostafa Fraidoon Faaek FAAEK ${ }^{1}$, ID Lütfi PIRLAK ${ }^{2 *}$

${ }^{1}$ Selçuk University, Faculty of Agriculture, Department of Horticulture, Selçuklu, Konya, Turkey

\begin{tabular}{l}
\hline ARTICLE INFO \\
\hline Article history: \\
Received date: 05.07 .2021 \\
Accepted date: 08.09 .2021 \\
\hline
\end{tabular}

Keywords:

Strawberry

Drought Stress

Morphological and Physiological Properties

\begin{abstract}
This study was carried out in the Selcuk University Faculty of Agriculture Department of Horticulture Research and practice greenhouse. In the study, Ata77, Bolverim77, Doruk77, Dorukhan77, Eren77, Erenoğlu77 and Hilal77 strawberry varieties obtained from Yalova Atatürk Horticultural Research Institute were used. Sewing 5-6 leaf stage seedlings strawberries made after the arrival of field capacity after the leaves of plants irrigation turgor until drought. After implementation of the varieties of drought with healing and drought period of watering again losses to determine. Leaf relative water content (LRWC) loss 15. by the end of the day up to Ata77 cultivar (51.51\%) while the cultivar Dorukhan77 with at least lost $29.74 \%$. Improvement of then 7 . day also represents the maximum improvement in the kind of Dorukhan77 (\% 5.38), while according to the day of check out lost $17.57 \%$ Ata77. Membrane permeability up to Ata77 cultivar $(91.32 \%)$ while the lowest membrane radicals Doruk77 $(71.46 \%)$. The drought is finally low stomatal conductivity Ata77 (10.70 mmol m-2 h-1) from the rubrics communicate the highest stomatal conductivity Doruk77 (106.76 mmol m-2 h-1) measured from. Measured in terms of the amount of chlorophyll in leaves, drought and recovery period maximum type of SPAD value from Eren77 (56.52 and 56.73) while Hilal77 the lowest values were obtained from (52.15 and 52.31). Body weight value of relative dry drought at the end of the implementation of the Doruk77 with the highest being obtained from $33.47 \mathrm{~g}$ minimum value has been obtained from Ata77 with $24.35 \mathrm{~g}$. In terms of relative root dry weight, the highest value is being obtained from $24.79 \mathrm{~g}$ Doruk77 with the minimum value has been obtained from Dorukhan77 with $18.44 \mathrm{~g}$. Leaf after leaf of the drought in the area measuring growth\% 2.57 cultivar Dorukhan77 with, while the lowest leaf growth is cultivar has been Doruk77 0.26\%.
\end{abstract}

\section{Introduction}

Strawberry is one of the important fruit species grown commercially in the world and in Turkey, and this importance is increasing. The commercially grown strawberry belongs to the Fragaria genus of the Rosaceae family and is included in the Fragaria $\mathrm{X}$ ananassa species, obtained by crossing Fragaria chiloensis and Fragaria virginiana species (Deuel and Plotto, 2004). Strawberry is a type of fruit that can easily adapt to different ecological conditions and climate types. As a matter of fact, it can be grown in different ecological conditions from Siberia to Ecuador, from places with high altitudes to places at sea level. Therefore, it can be grown in almost every region in Turkey. Strawberry production is mostly carried out in the Mediterranean and Aegean regions of Turkey, and over time,

\footnotetext{
* Corresponding author email: pirlak@selcuk.edu.tr
}

**This work is part of first author's $\mathrm{PhD}$ thesis strawberries have been grown in other regions of Turkey. In the world, especially China, USA, Mexico, Turkey, Spain, Egypt are important strawberry producer countries (Anonymous, 2021).

Today, drought has reached social and economic dimensions that threaten the environment and countries with the increase in the world population, climate changes, deforestation and global warming. Drought is one of the natural disasters that cause the most damage to people and the environment and cause great losses. It is estimated that Turkey is among the countries with a high risk group in terms of the possible effects of global warming, and that especially the Mediterranean and Central Anatolia regions will be more affected by climate change in the future. Turkey has very different climatic zones and microclimate areas due to its geographical location and structure. Climate elements and especially the precipitation factor, which has the greatest impact on production, show great temporal and spatial changes. Although the annual precipitation average in Turkey is around $640 \mathrm{~mm}$, water shortage 
and drought are experienced in many regions due to the irregularity of the precipitation distribution (Özcan et al., 2004). Among the main factors affecting drought in Turkey are atmospheric conditions, physical geography factors and climatic conditions (Anonymous, 2008). Drought stress caused by the lack of moisture necessary for the plant to grow normally and complete its life cycle; It is common in regions where rainfall is irregular and irrigation is weak (Sircelj et al., 2007). Drought is a meteorological phenomenon in general terms and is defined as the period when there is no precipitation until the water content of the soil and plant growth decreases significantly and the water shortage reaches the amount that will cause distress (Özcan et al., 2004). In drought conditions, the water potential of the soil and then the plant decreases. In the later stages, low turgor pressure, closure of stomata, decrease in leaf growth and decrease in photosynthesis rate occur. Plants exposed to drought stress have limited growth, lower dry matter production, increased susceptibility to diseases and pests, and decreased product quality and quantity (Monti, 1987).

Plants to drought stress; they respond with the change they show in morphological, biochemical and metabolic processes (Romo et al., 2001). As a result, plants exposed to water scarcity are more sensitive to other biotic and abiotic stresses (Coruso et al., 2008).

Global warming, which is seen as a potential threat to agricultural production in the future and whose impact we feel increasing day by day, will necessitate the determination of drought tolerance of existing cultivars and the cultivation of new drought-tolerant genotypes. For this purpose, in this study, the drought stress of 7 short-day strawberry cultivars, Bolverim77, Hilal77, Doruk77, Dorukhan77, Ata77, Eren77, Erenoğlu77, breeding in Yalova Atatürk Horticultural Central Research Institute.

\section{Materials and Methods}

\subsection{Materials}

This research was carried out in the greenhouse of the Department of Horticulture, Faculty of Agriculture, Selcuk University in 2016-2017. The plants were grown under sunlight, at an average temperature of $31 / 22$ (day/night) and approximately relative humidity $\%$ 60-70 during the growing period. In the research, 7 strawberry cultivars, Bolverim77, Hilal77, Doruk77, Dorukhan77, Ata77, Eren77, Erenoğlu77, which were breeding in Yalova Atatürk Horticultural Central Research Institute, were used. Characteristics of the strawberry cultivars below.

ATA77: Tioga x Cruz hybrid. Its fruits are medium large, the outer color of the fruit is bright red, the fruit flesh is hard, the fruit is heart-shaped, the taste and smell are very good (Anonymous, 2017).

EREN77: Ottoman x Tufts hybrid. Its fruits are medium large, conical in shape, the outer color of the fruit is bright red, the taste and smell is very good, the fruit quality is good and the fruit flesh is hard (Anonymous, 2017).

HILAL77: Ottoman x Tufts hybrid. Its fruits are medium-large, heart-shaped, the outer color of the fruit is bright red, the taste and smell is very good, the fruit quality is good and the fruit flesh is hard (Anonymous, 2017).

BOLVERIM77: Tioga x Yalova-104 hybrid. The fruits are large, the outer color of the fruit is bright light red, the hardness of the fruit is medium, the shape is flattened, the fruit taste is medium (Anonymous, 2017).

DORUK77: Tufts x Cruz hybrid. The fruits are small, the outer color of the fruit is bright red, the fruit flesh is quite hard. It is suitable for the food industry and can also be used as a table (Anonymous, 2017).

DORUKHAN77: Tufts x Cruz hybrid. The fruits are medium-large, the outer color of the fruit is bright red, the fruit flesh is hard. It is quite efficient. Although it is table quality, it is also suitable for the food industry (Anonymous, 2017).

ERENOĞLU77: Cruz x Tioga hybrid. The fruits are large, the outer color of the fruit is bright red, the fruit flesh is medium hard. Fruit quality is very good (Anonymous, 2017).

\subsection{Methods}

In the study, frigo strawberry seedlings were planted in 3-liter pots filled with peat. After the seedlings are planted, the flowers and branches are plucked until they reach the 5-6 leaf stage, and vegetative development of the plants is ensured. The seedlings used in the study were selected with equal vigor. The seedlings, whose development was completed, were irrigated at the field capacity level and no irrigation was applied until the first sign of drought (withering of the leaves). After the first sign of drought, the plants were started to be watered again and the recovery vitality was maintained.

The study was planned on 7 strawberry cultivars with a 15-day drought application followed by reirrigation of the plants. In the study, there were 3 replications and 3 plants in each replication. In the study, morphological measurements of leaf area, plant fresh and dry weight, root fresh and dry weight were made. In addition, physiologically membrane permeability, leaf proportional water content, stomatal conductivity and chlorophyll content measurements were made.

The mature leaves from the plants were measured with the Winfolia leaf area meter program. Measurements were made on 10 leaves selected by chance from plants belonging to each application (İpek et al., 2014).

At the end of the research, the parts of the plants removed from the pots, except for the root parts, were first kept in an oven at $72^{\circ} \mathrm{C}$ for 48 hours after their wet weight, and their dry weight was determined by weighing them with precision scales (İpek et al., 2014).

At the end of the study, the roots, excluding the plant green parts of the plants removed from the pots, 
were first taken from the wet weight and kept in an oven at $72^{\circ} \mathrm{C}$ for 48 hours, and their dry weight was determined by weighing them with a precision balance (İpek et al., 2014).

For membrane permeability, 3 leaf discs, each 1 $\mathrm{cm} 2$ in size, were taken and passed through distilled water 3 times in glass tubes. After this process, $10 \mathrm{ml}$ of water was added and shaken in closed vials at $25^{\circ} \mathrm{C}$ for 24 hours. Immediately afterwards, EC was measured $(\mathrm{C} 1)$, the same samples were kept in an autoclave at $120^{\circ} \mathrm{C}$ for 20 minutes, then cooled down to $25^{\circ} \mathrm{C}$ and then EC was measured again $(\mathrm{C} 2)$. Membrane permeability was determined by the following formula (Lutts et al., 1996).

Membrane Permeability $=\mathrm{C} 1 / \mathrm{C} 2 \times 100$

The leaf discs taken from the plants were weighed and their wet weight was determined, then they were kept in petri dishes filled with pure water in an airtight manner and weighed and their turgor weight was taken. Then, the leaf discs were kept in an oven at $72^{\circ} \mathrm{C}$ for 48 hours and their dry weight was weighed, and the relative water content was calculated according to the formula below (Kaya et al., 2003).

LRWC $(\%)=($ WT-FW $) /($ WT-DW $) \times 100$

LRWC $=$ Leaf Relative Water Content

$\mathrm{FW}=$ Fresh Weight

DW $=$ Dry Weight

WT $=$ Weight in Turgor State

Gas exchange in the leaves was measured with the "Leaf Porometer" device from the middle part of the randomly selected leaves from the plants. These measurements were made during the drought phase and on the first day of the healing process (Kuşçu, 2006).

Table 1

Effects of drought stress on leaf area $\left(\mathrm{cm}^{2}\right)$ in strawberry cultivars

\begin{tabular}{|c|c|c|c|c|c|c|c|c|}
\hline \multirow[b]{2}{*}{ Cultivars } & \multicolumn{4}{|c|}{2016} & \multicolumn{4}{|c|}{2017} \\
\hline & 0. day & $\begin{array}{l}\text { 15. day } \\
\text { control }\end{array}$ & $\begin{array}{l}\text { 15. day } \\
\text { drought }\end{array}$ & $\begin{array}{l}\text { 7. day } \\
\text { recovery }\end{array}$ & 0 . day & $\begin{array}{l}\text { 15. day } \\
\text { control }\end{array}$ & $\begin{array}{l}\text { 15. day } \\
\text { drought }\end{array}$ & $\begin{array}{c}\text { 7. day } \\
\text { recovery }\end{array}$ \\
\hline Doruk77 & $16.27 \mathrm{~d}$ & $16.95 \mathrm{~d}$ & $16.50 \mathrm{~d}$ & $16.56 \mathrm{~d}$ & $17.63 \mathrm{e}$ & $18.55 \mathrm{c}$ & $17.76 \mathrm{~d}$ & $17.80 \mathrm{~d}$ \\
\hline Dorukhan77 & $22.41 \mathrm{c}$ & $23.10 \mathrm{c}$ & $22.51 \mathrm{c}$ & $22.66 \mathrm{c}$ & $21.92 \mathrm{~d}$ & $22.65 b$ & $22.09 \mathrm{c}$ & $22.22 \mathrm{c}$ \\
\hline Hilal77 & $30.20 \mathrm{a}$ & $30.85 \mathrm{a}$ & $30.31 \mathrm{a}$ & $30.41 \mathrm{a}$ & $30.09 \mathrm{a}$ & $31.01 \mathrm{a}$ & $30.27 \mathrm{a}$ & $30.32 \mathrm{a}$ \\
\hline Bolverim77 & $27.58 \mathrm{~b}$ & $28.65 \mathrm{~b}$ & $27.97 \mathrm{~b}$ & $28.05 \mathrm{~b}$ & $28.75 \mathrm{bc}$ & $30.10 \mathrm{a}$ & $29.02 \mathrm{ab}$ & $29.20 \mathrm{ab}$ \\
\hline Eren77 & $27.43 b$ & $28.30 \mathrm{~b}$ & $27.82 b$ & $27.95 \mathrm{~b}$ & $27.57 \mathrm{c}$ & $29.21 \mathrm{a}$ & $27.82 \mathrm{~b}$ & $27.88 \mathrm{~b}$ \\
\hline Erenoğlu77 & $22.99 \mathrm{c}$ & $24.02 \mathrm{bc}$ & $23.23 \mathrm{c}$ & $23.33 \mathrm{c}$ & $23.06 \mathrm{~d}$ & $24.12 \mathrm{~b}$ & $23.23 \mathrm{c}$ & $23.27 \mathrm{c}$ \\
\hline Ata77 & $28.29 \mathrm{~b}$ & $28.78 \mathrm{~b}$ & $28.50 \mathrm{~b}$ & $28.41 \mathrm{~b}$ & $29.94 \mathrm{ab}$ & $30.90 \mathrm{a}$ & $30.18 \mathrm{a}$ & $30.27 \mathrm{a}$ \\
\hline LSD & 1.90 & 4.81 & 1.94 & 1.87 & 1.90 & 3.99 & 1.91 & 1.93 \\
\hline
\end{tabular}

*: There is no difference between the averages shown with the same letter in the same column

\section{Plant fresh weight}

At the end of the drought stress, there was a slight increase in plant fresh weight, and even a decrease in some cultivars. In the control application in 2016, the cultivars with the highest dry weight were Ata77 and Eren77, and the lowest cultivars were Doruk77 and Erenoğlu77. In drought application, the highest dry weight of the plant is Erenoğlu77 and the lowest is Doruk77. In the control application of 2017, the culti-
The present study used a completely randomized design, including three replicates per treatment and 5 plants per replicates. All data was subjected to one-way ANOVA. The Duncan's multiple range test was used to compare mean values at $\mathrm{p}<0.05$ by SPSS 23.0 software.

\section{Results and Discussion}

\subsection{Results}

\section{Leaf area}

With the effect of 15-day drought stress, there was almost no increase in the leaf area of the plants. The effects of drought stress on strawberry cultivars were found to be statistically significant. In 2016, the variety with the highest leaf area was Hilal77 and the lowest variety was Doruk77 in control, drought and recovery applications (Table 1.) In 2016, the highest leaf growth was in Eren 77 during the drought and recovery period. Leaf area decreased between $0.97 \%$ and $3.28 \%$ compared to the control group in drought application. The highest decrease in leaf area occurred in Erenoğlu 77, the lowest decrease occurred in Ata77 cultivar.

The results of 2017 were generally similar to the results of 2016. This year, the most leaf area was determined in Hilal77 and the least in Doruk77 variety in control, drought and recovery applications (Table 1). During the drought and recovery period in 2017, the highest leaf growth occurred in Bolverim77 cultivar. Leaf area decreased between $2.33 \%$ and $4.25 \%$ in drought application compared to the control group. The highest decrease in leaf area occurred in Doruk 77, the lowest decrease occurred in Ata77 cultivar. vars with the highest dry weight were found to be Ata77 and Eren77, and the lowest was Doruk77. In drought application, the highest dry weight of the plant is Erenoğlu77 and the lowest is Hilal77. In 2016, the highest decrease in plant fresh weights occurred in Bolverim 77, and the lowest decrease occurred in Erenoğlu 77 cultivar. In 2017, the highest decrease in plant fresh weights was detected in Eren 77, and the lowest decrease in Ata77 cultivar (Table 2). 
Table 2

Effect of drought stress on plant fresh weight $(\mathrm{g})$ in strawberry cultivars

\begin{tabular}{|c|c|c|c|c|c|c|}
\hline \multirow{2}{*}{ Cultivars } & \multicolumn{3}{|c|}{2016} & \multicolumn{3}{|c|}{2017} \\
\hline & 0. day & 15. day control & 15. day drought & 0. day & 15. day control & 15. day drought \\
\hline Doruk77 & $39.35 \mathrm{~d}$ & $44.25 \mathrm{e}$ & $42.11 \mathrm{~g}$ & $35.99 \mathrm{~d}$ & $40.12 \mathrm{~d}$ & $37.57 \mathrm{f}$ \\
\hline Dorukhan77 & $45.16 \mathrm{c}$ & $54.23 \mathrm{~d}$ & $51.74 \mathrm{f}$ & $38.15 \mathrm{bc}$ & $49.26 \mathrm{c}$ & $46.50 \mathrm{~d}$ \\
\hline Hilal77 & $52.66 \mathrm{~b}$ & $58.36 \mathrm{c}$ & $55.50 \mathrm{e}$ & $37.66 \mathrm{c}$ & $41.14 \mathrm{~d}$ & $35.77 \mathrm{~g}$ \\
\hline Bolverim77 & $51.67 \mathrm{~b}$ & $68.53 \mathrm{a}$ & $61.16 \mathrm{~b}$ & $39.67 \mathrm{~b}$ & $55.24 \mathrm{~b}$ & $49.04 \mathrm{~b}$ \\
\hline Eren77 & $59.48 \mathrm{a}$ & $64.35 \mathrm{~b}$ & $58.51 \mathrm{~d}$ & $45.24 \mathrm{a}$ & $50.58 \mathrm{c}$ & $41.49 \mathrm{e}$ \\
\hline Erenoğlu77 & $40.20 \mathrm{~d}$ & $63.87 \mathrm{~b}$ & $61.83 \mathrm{a}$ & $31.93 \mathrm{e}$ & $60.05 \mathrm{a}$ & $52.10 \mathrm{a}$ \\
\hline Ata77 & $58.61 \mathrm{a}$ & $63.28 \mathrm{~b}$ & $60.30 \mathrm{c}$ & $45.76 \mathrm{a}$ & $49.69 \mathrm{c}$ & $47.13 \mathrm{c}$ \\
\hline LSD & 2.38 & 4.02 & 0.94 & 2.93 & 3.86 & 0.59 \\
\hline
\end{tabular}

*: There is no difference between the averages shown with the same letter in the same column

\section{Plant dry weight}

It has been determined that the effects of drought stress differ according to the cultivars. In the control application in 2016, the highest dry weight of the plant was Doruk77 (19.53 g) and the lowest was Erenoğlu77 (13.32 g). In drought application, the highest dry weight of the plant is Ata77 (26.57 g), and the lowest is Eren77 $(18.16 \mathrm{~g})$. The highest decrease in plant dry weights was found in Doruk77, and the lowest decrease

Table 3

Effect of drought stress on plant dry weight $(\mathrm{g})$ in strawberry cultivars

\begin{tabular}{|c|c|c|c|c|c|c|}
\hline \multirow{2}{*}{ Cultivars } & \multicolumn{3}{|c|}{2016} & \multicolumn{3}{|c|}{2017} \\
\hline & 0. day & 15. day control & 15. day drought & 0. day & 15. day control & 15. day drought \\
\hline Doruk77 & $19.53 \mathrm{a}$ & $27.56 \mathrm{~b}$ & $25.34 \mathrm{~b}$ & $21.68 \mathrm{a}$ & $23.52 \mathrm{a}$ & $17.35 \mathrm{ab}$ \\
\hline Dorukhan77 & $16.66 \mathrm{bc}$ & $28.45 \mathrm{ab}$ & $25.64 \mathrm{~b}$ & $19.35 \mathrm{~b}$ & $24.66 \mathrm{a}$ & $15.70 \mathrm{c}$ \\
\hline Hilal77 & $14.97 \mathrm{~cd}$ & $23.45 \mathrm{~d}$ & $20.17 \mathrm{e}$ & $14.39 \mathrm{~d}$ & $17.10 \mathrm{c}$ & $13.65 \mathrm{e}$ \\
\hline Bolverim77 & $15.85 \mathrm{bc}$ & $26.89 \mathrm{bc}$ & $22.61 \mathrm{c}$ & $16.83 \mathrm{c}$ & $19.51 \mathrm{~b}$ & $17.05 \mathrm{~b}$ \\
\hline Eren77 & $16.99 \mathrm{~b}$ & $23.44 \mathrm{~d}$ & $18.16 \mathrm{f}$ & $13.77 \mathrm{~d}$ & $16.53 \mathrm{c}$ & $14.46 \mathrm{~d}$ \\
\hline Erenoğlu77 & $13.32 \mathrm{~d}$ & $24.61 \mathrm{~cd}$ & $21.36 \mathrm{~d}$ & $13.87 \mathrm{~d}$ & $20.30 \mathrm{~b}$ & $17.74 \mathrm{a}$ \\
\hline Ata77 & $16.61 \mathrm{bc}$ & $29.47 \mathrm{a}$ & $26.57 \mathrm{a}$ & $17.50 \mathrm{bc}$ & $20.46 \mathrm{~b}$ & $16.99 \mathrm{~b}$ \\
\hline LSD & 2.70 & 2.95 & 0.74 & 3.00 & 3.11 & 0.85 \\
\hline
\end{tabular}

*: There is no difference between the averages shown with the same letter in the same column

\section{Root fresh weight}

Significant differences were determined in root fresh and dry weights of cultivars according to the applications (Table 4). In 2016, root wet weight was $15.30 \mathrm{~g}$ (Doruk77) and 23.71 g (Ata77); In drought application, it was found between $18.92 \mathrm{~g}$ (Doruk77) and $23.35 \mathrm{~g}$ (Hilal77). Root wet weights decreased between $18.90 \%$ and $8.10 \%$ compared to the control

Table 4

The effect of drought stress on root fresh weight $(\mathrm{g})$ in strawberry cultivars.

\begin{tabular}{|c|c|c|c|c|c|c|}
\hline \multirow{2}{*}{ Cultivars } & \multicolumn{3}{|c|}{2016} & \multicolumn{3}{|c|}{2017} \\
\hline & 0. day & 15. day control & 15. day drought & 0. day & 15. day control & 15. day drought \\
\hline Doruk77 & $15.30 \mathrm{e}$ & $23.33 \mathrm{~d}$ & $18.92 \mathrm{e}$ & $9.63 \mathrm{~d}$ & $14.22 \mathrm{~d}$ & $12.33 \mathrm{~d}$ \\
\hline Dorukhan77 & $19.35 \mathrm{~d}$ & $24.16 \mathrm{~cd}$ & $21.87 \mathrm{~d}$ & $12.61 \mathrm{c}$ & $17.40 \mathrm{c}$ & $15.06 \mathrm{c}$ \\
\hline Hilal77 & $20.68 \mathrm{c}$ & $25.41 \mathrm{bc}$ & $23.35 \mathrm{a}$ & $18.31 \mathrm{a}$ & $20.00 \mathrm{ab}$ & $16.21 \mathrm{ab}$ \\
\hline Bolverim77 & $19.91 \mathrm{~cd}$ & $26.85 \mathrm{ab}$ & $22.62 \mathrm{bc}$ & $17.08 \mathrm{a}$ & $20.36 \mathrm{a}$ & $17.01 \mathrm{a}$ \\
\hline Eren 77 & $22.66 \mathrm{~b}$ & $27.45 \mathrm{a}$ & $22.88 \mathrm{ab}$ & $14.85 \mathrm{~b}$ & $18.24 \mathrm{bc}$ & $14.96 \mathrm{c}$ \\
\hline Erenoğlu77 & $21.79 \mathrm{~b}$ & $23.63 \mathrm{~d}$ & $21.68 \mathrm{~d}$ & $12.33 \mathrm{c}$ & $14.03 \mathrm{~d}$ & $13.32 \mathrm{~d}$ \\
\hline Ata77 & $23.71 \mathrm{a}$ & $25.10 \mathrm{bc}$ & $22.10 \mathrm{~cd}$ & $12.47 \mathrm{c}$ & $17.09 \mathrm{c}$ & $15.41 \mathrm{bc}$ \\
\hline LSD & 1.27 & 2.29 & 1.03 & 2.07 & 2.83 & 1.62 \\
\hline
\end{tabular}

*: There is no difference between the averages shown with the same letter in the same column

\section{Root dry weight}

Significant differences were determined in root dry weights of cultivars according to the applications. In 2016, root dry weight was $5.86 \mathrm{~g}$ (Ata77) and $7.80 \mathrm{~g}$ (Dorukhan77); In drought application, it was found between $6.40 \mathrm{~g}$ (Erenoğlu77) and $8.75 \mathrm{~g}$ (Doruk77). In 2017, the root dry weight was $3.03 \mathrm{~g}$ (Eren77) and 5.96 group in drought application. The highest decrease in root fresh weight was found in Hilal77, and the lowest decrease was found in Doruk77 cultivar. In 2017, root wet weight was $9.63 \mathrm{~g}$ (Doruk77) and $18.31 \mathrm{~g}$ (Hilal77); in drought application, it is between $12.33 \mathrm{~g}$ (Doruk77) and 17.01 g (Bolverim77). The highest decrease in root fresh weights was detected in Erenoğlu77, the lowest decrease in Eren77 cultivar (Table 4). was in Eren77 cultivar. In the control application in ned as Doruk77 (21.68 g) and the lowest was Eren77 (13.77 g). In drought application, Erenoğlu77 (17.74 g) has the highest dry weight of the plant, and Hilal77 dry weights occurred in Eren 77 , and the least decrease occurred in Dorukhan 77 cultivar (Table 3). 
Table 5

Effect of drought stress on root dry weight $(\mathrm{g})$ in strawberry cultivars

\begin{tabular}{|c|c|c|c|c|c|c|}
\hline \multirow{2}{*}{ Cultivars } & \multicolumn{3}{|c|}{2016} & \multicolumn{3}{|c|}{2017} \\
\hline & 0 . day & 15. day control & 15. day drought & 0. day & 15. day control & 15. day drought \\
\hline Doruk77 & $7.30 \mathrm{ab}$ & $9.10 \mathrm{ab}$ & $8.75 \mathrm{a}$ & $4.35 \mathrm{bc}$ & $8.11 \mathrm{ab}$ & $7.30 \mathrm{a}$ \\
\hline Dorukhan77 & $7.80 \mathrm{a}$ & $9.24 \mathrm{ab}$ & $8.70 \mathrm{a}$ & $4.73 b$ & $8.19 \mathrm{a}$ & $7.42 \mathrm{a}$ \\
\hline Hilal77 & $6.40 \mathrm{~cd}$ & $9.04 \mathrm{a}$ & $8.46 \mathrm{ab}$ & $5.96 \mathrm{a}$ & $7.33 \mathrm{abc}$ & $6.45 \mathrm{~b}$ \\
\hline Bolverim77 & $7.16 \mathrm{~b}$ & $8.86 \mathrm{ab}$ & $8.29 \mathrm{bc}$ & $3.77 \mathrm{~cd}$ & $7.19 \mathrm{c}$ & $6.71 \mathrm{~b}$ \\
\hline Eren 77 & $6.41 \mathrm{~cd}$ & $8.75 \mathrm{ab}$ & $7.98 \mathrm{~cd}$ & $3.03 \mathrm{~d}$ & $6.46 \mathrm{abc}$ & $5.47 \mathrm{c}$ \\
\hline Erenoğlu77 & $6.78 \mathrm{bc}$ & $7.50 \mathrm{~b}$ & $6.40 \mathrm{e}$ & $3.74 \mathrm{~cd}$ & $6.23 \mathrm{bc}$ & $5.52 \mathrm{c}$ \\
\hline Ata77 & $5.86 \mathrm{~d}$ & $8.36 \mathrm{ab}$ & $7.65 \mathrm{~d}$ & $4.44 \mathrm{bc}$ & $6.14 \mathrm{c}$ & $5.24 \mathrm{c}$ \\
\hline LSD & 0.80 & 3.05 & 0.54 & 1.19 & 2.95 & 0.74 \\
\hline
\end{tabular}

*: There is no difference between the averages shown with the same letter in the same column

\section{Membrane permeability}

The results of membrane permeability in leaf samples of strawberry cultivars are given in Table 6 . As the level of drought severity increases, it is seen that membrane damage increases with the increase in membrane permeability percentages. According to the data of 2016, the membrane damage differed in the cultivars, and the least damage occurred in Doruk77 $(71.46 \%)$ and Ata77 (91.32\%) the most in the drought period. In the recovery period, the least damage was detected in Doruk77 (35.73\%), and the most in Ata77

Table 6

Effect of drought stress on membrane permeability (\%) in strawberry cultivars

\begin{tabular}{|c|c|c|c|c|c|c|c|c|}
\hline \multirow[b]{2}{*}{ Cultivars } & \multicolumn{4}{|c|}{2016} & \multicolumn{4}{|c|}{2017} \\
\hline & 0 . day & $\begin{array}{l}\text { 15. day } \\
\text { control }\end{array}$ & $\begin{array}{l}\text { 15. day } \\
\text { drought }\end{array}$ & $\begin{array}{l}\text { 7. day } \\
\text { recovery }\end{array}$ & 0 . day & $\begin{array}{l}\text { 15. day } \\
\text { control }\end{array}$ & $\begin{array}{l}\text { 15. day } \\
\text { drought }\end{array}$ & $\begin{array}{l}\text { 7. day } \\
\text { recovery }\end{array}$ \\
\hline Doruk77 & $17.71 \mathrm{ab}$ & $21.10 \mathrm{a}$ & $71.46 \mathrm{e}$ & $35.73 \mathrm{~d}$ & $17.52 \mathrm{~cd}$ & $23.60 \mathrm{a}$ & $61.67 \mathrm{e}$ & $22.07 \mathrm{~d}$ \\
\hline Dorukhan77 & $16.64 \mathrm{bc}$ & $18.36 \mathrm{bc}$ & $73.70 \mathrm{e}$ & $37.07 \mathrm{c}$ & $20.09 \mathrm{a}$ & $22.00 \mathrm{ab}$ & $62.57 \mathrm{e}$ & $27.48 \mathrm{bc}$ \\
\hline Hilal77 & $15.71 \mathrm{c}$ & $16.70 \mathrm{c}$ & $82.45 \mathrm{~d}$ & $41.39 \mathrm{~b}$ & $16.13 \mathrm{e}$ & $18.00 \mathrm{c}$ & $72.77 \mathrm{~d}$ & $26.29 \mathrm{bc}$ \\
\hline Bolverim77 & $16.61 \mathrm{bc}$ & $18.00 \mathrm{bc}$ & $83.54 \mathrm{~cd}$ & $41.83 \mathrm{~b}$ & $17.92 \mathrm{bc}$ & $19.30 \mathrm{bc}$ & $73.54 \mathrm{~cd}$ & $27.94 \mathrm{~b}$ \\
\hline Eren77 & $17.75 \mathrm{ab}$ & $18.24 \mathrm{bc}$ & $84.91 \mathrm{c}$ & $42.43 \mathrm{~b}$ & $16.50 \mathrm{de}$ & $18.45 \mathrm{bc}$ & $75.26 \mathrm{bc}$ & $26.00 \mathrm{c}$ \\
\hline Erenoğlu77 & $17.64 \mathrm{ab}$ & $18.35 \mathrm{bc}$ & $87.17 \mathrm{~b}$ & $43.84 \mathrm{a}$ & $19.08 \mathrm{ab}$ & $19.87 \mathrm{bc}$ & $76.06 \mathrm{~b}$ & $30.25 \mathrm{a}$ \\
\hline Ata77 & $18.10 \mathrm{a}$ & $19.14 \mathrm{ab}$ & $91.32 \mathrm{a}$ & $44.58 \mathrm{a}$ & $18.57 \mathrm{bc}$ & $20.35 a b c$ & $82.14 \mathrm{a}$ & $30.98 \mathrm{a}$ \\
\hline LSD & 1.74 & 3.29 & 2.10 & 1.84 & 1.80 & 4.98 & 2.76 & 2.69 \\
\hline
\end{tabular}

*: There is no difference between the averages shown with the same letter in the same column

\section{Leaf relative water content}

As a result of leaf relative water content measurements, it was found that the applications were statistically significant. In 2016, the highest LRWC value was observed in the cultivar Doruk77 $(81.88 \%)$, followed by Dorukhan $77(80.40 \%)$, and the lowest value was determined in the cultivar Bolverim77 (78.27\%). During the drought period, LRWC Doruk77 (68.77\%) was the highest and the lowest was found in Ata77 (52.48\%). Similarly, the highest LRWC Doruk77 $(88.24 \%)$ and the lowest Ata77 $(71.82 \%)$ variety were found during the recovery period. The highest decrease Table 7

Effect of drought stress on leaf relative water content (LRWC) (\%) in strawberry cultivars

\begin{tabular}{|c|c|c|c|c|c|c|c|c|}
\hline \multirow[b]{2}{*}{ Cultivars } & \multicolumn{4}{|c|}{2016} & \multicolumn{4}{|c|}{2017} \\
\hline & 0 . day & $\begin{array}{l}\text { 15. day } \\
\text { control }\end{array}$ & $\begin{array}{l}\text { 15. day } \\
\text { drought }\end{array}$ & $\begin{array}{l}\text { 7. day } \\
\text { recovery }\end{array}$ & 0 . day & $\begin{array}{l}\text { 15. day } \\
\text { control }\end{array}$ & $\begin{array}{l}\text { 15. day } \\
\text { drought }\end{array}$ & $\begin{array}{l}\text { 7. day } \\
\text { recovery }\end{array}$ \\
\hline Doruk77 & $81.88 \mathrm{a}$ & $80.14 \mathrm{abc}$ & $68.77 \mathrm{a}$ & $88.24 \mathrm{a}$ & $86.85 \mathrm{~b}$ & $80.36 \mathrm{c}$ & $74.19 \mathrm{a}$ & $87.17 \mathrm{~b}$ \\
\hline Dorukhan77 & $80.40 \mathrm{~b}$ & $82.65 \mathrm{a}$ & $62.66 \mathrm{~b}$ & $83.50 \mathrm{~b}$ & $93.19 \mathrm{a}$ & $90.01 \mathrm{a}$ & $74.20 \mathrm{a}$ & $96.48 \mathrm{a}$ \\
\hline Hilal77 & $78.53 \mathrm{de}$ & $79.63 \mathrm{~d}$ & $60.39 c$ & $75.28 \mathrm{c}$ & $74.58 \mathrm{~d}$ & $75.10 \mathrm{~d}$ & $58.40 \mathrm{bc}$ & $74.93 \mathrm{de}$ \\
\hline Bolverim77 & $78.27 \mathrm{e}$ & $80.00 \mathrm{abc}$ & $57.86 \mathrm{~d}$ & $75.50 \mathrm{c}$ & $82.52 \mathrm{c}$ & $83.25 \mathrm{~b}$ & $60.32 \mathrm{~b}$ & $77.69 \mathrm{~cd}$ \\
\hline Eren77 & $79.54 \mathrm{c}$ & $81.74 \mathrm{ab}$ & $57.48 \mathrm{~d}$ & $73.41 \mathrm{~d}$ & $84.62 \mathrm{bc}$ & $84.00 \mathrm{~b}$ & $56.19 \mathrm{c}$ & $84.29 \mathrm{~b}$ \\
\hline Erenoğlu77 & $78.69 \mathrm{de}$ & $79.96 \mathrm{~cd}$ & $56.09 \mathrm{e}$ & $74.00 \mathrm{~d}$ & $84.85 \mathrm{bc}$ & $85.63 \mathrm{~b}$ & $57.22 \mathrm{c}$ & $78.21 \mathrm{c}$ \\
\hline Ata77 & $79.11 \mathrm{~cd}$ & $81.38 \mathrm{ab}$ & $52.48 \mathrm{f}$ & $71.82 \mathrm{e}$ & $85.04 \mathrm{bc}$ & $84.52 \mathrm{~b}$ & $50.50 \mathrm{~d}$ & $72.65 \mathrm{e}$ \\
\hline LSD & 1.06 & 2.92 & 0.83 & 1.11 & 4.51 & 2.91 & 3.45 & 4.51 \\
\hline
\end{tabular}

*: There is no difference between the averages shown with the same letter in the same column

in leaf relative water content was determined in Doruk77, and the lowest decrease in Ata77 cultivar. In 2017, the highest LRWC Dorukhan77 (93.19\%) was found in the control, and the lowest was found in Hilal77 variety. At the end of the 15-day drought application, the highest LRWC was found in Dorukhan77 variety, while the lowest value was determined in Ata77. In the recovery period after the drought, the highest value was again found in Dorukhan 77 and the lowest in Ata77. The highest decrease in leaf relative water content was determined in Doruk77, and the lowest decrease in Ata77 (Table 7).
(44.58\%). The highest increase in membrane permeabi77 variety. In 2017, the least damage occurred in Doruk77 $(61.67 \%)$ variety, followed by Dorukhan77 $(62.57 \%)$, and Ata77 (82.14\%) variety was the most was determined in Doruk77 with $22.07 \%$ and the highest damage was determined in Ata77 with $30.98 \%$. The highest increase in membrane permeability was determined in Doruk 77, the lowest increase in Hilal 77 variety (Table 6) 


\section{Stomatal conductivity}

Drought application caused great decreases in stomatal conductivity in strawberry cultivars. While the highest decreases were found in Hilal77, Bolverim77, Eren77, Erenoğlu77 and Ata cultivars compared to control in 2016, the decreases were less in Doruk77 Table 8

Effects of drought stress on stomatal conductivity in strawberry cultivars.

\begin{tabular}{|c|c|c|c|c|c|c|c|c|}
\hline \multirow[b]{2}{*}{ Cultivars } & \multicolumn{4}{|c|}{2016} & \multicolumn{4}{|c|}{2017} \\
\hline & 0 . day & $\begin{array}{l}\text { 15. day } \\
\text { control }\end{array}$ & $\begin{array}{l}\text { 15. day } \\
\text { drought }\end{array}$ & $\begin{array}{l}\text { 7. day } \\
\text { recovery }\end{array}$ & 0 . day & $\begin{array}{l}\text { 15. day } \\
\text { control }\end{array}$ & $\begin{array}{l}\text { 15. day } \\
\text { drought }\end{array}$ & $\begin{array}{l}\text { 7. day } \\
\text { recovery }\end{array}$ \\
\hline Doruk77 & $358.37 \mathrm{a}$ & $365.00 \mathrm{a}$ & $116.63 \mathrm{a}$ & $373.67 \mathrm{a}$ & $355.86 \mathrm{a}$ & $358.14 \mathrm{a}$ & $106.49 \mathrm{a}$ & $368.33 \mathrm{a}$ \\
\hline Dorukhan77 & $345.70 \mathrm{~b}$ & $348.30 \mathrm{bc}$ & $112.44 \mathrm{~b}$ & $366.07 \mathrm{c}$ & $343.76 \mathrm{~b}$ & $340.15 \mathrm{~d}$ & $103.03 \mathrm{~b}$ & $355.96 \mathrm{~b}$ \\
\hline Hilal77 & $339.26 \mathrm{c}$ & $350.87 \mathrm{bc}$ & $37.63 \mathrm{~d}$ & $358.83 \mathrm{~d}$ & $338.06 \mathrm{c}$ & $340.15 \mathrm{~d}$ & $16.73 \mathrm{~cd}$ & $364.65 \mathrm{a}$ \\
\hline Bolverim77 & $348.93 \mathrm{~b}$ & $351.36 \mathrm{abc}$ & $39.49 \mathrm{c}$ & $368.20 \mathrm{~b}$ & $344.30 \mathrm{~b}$ & $344.90 \mathrm{c}$ & $17.19 \mathrm{c}$ & $370.51 \mathrm{a}$ \\
\hline Eren77 & $340.20 \mathrm{c}$ & $341.25 \mathrm{c}$ & $39.18 \mathrm{c}$ & $366.23 \mathrm{bc}$ & $338.20 \mathrm{c}$ & $340.52 \mathrm{~d}$ & $16.81 \mathrm{~cd}$ & $365.76 \mathrm{a}$ \\
\hline Erenoğlu77 & $328.43 \mathrm{~d}$ & $328.70 \mathrm{~d}$ & $38.97 \mathrm{~cd}$ & $366.47 \mathrm{bc}$ & $325.43 \mathrm{~d}$ & $328.40 \mathrm{e}$ & $16.07 \mathrm{~d}$ & $367.50 \mathrm{a}$ \\
\hline Ata77 & $359.10 \mathrm{a}$ & $362.13 \mathrm{ab}$ & $23.34 \mathrm{e}$ & $353.90 \mathrm{e}$ & $356.83 \mathrm{a}$ & $350.36 \mathrm{~b}$ & $10.77 \mathrm{e}$ & $351.36 \mathrm{~b}$ \\
\hline LSD & 4.98 & 2.45 & 2.05 & 2.79 & 5.61 & 2.98 & 1.40 & 9.62 \\
\hline
\end{tabular}

*: There is no difference between the averages shown with the same letter in the same column

\section{SPAD value}

In 2016 and 2017, the SPAD value in strawberry leaves decreased a little as a result of drought application, but returned to the control level during the reco-

Table 9

Effect of drought stress on SPAD value in strawberry cultivars

\begin{tabular}{|c|c|c|c|c|c|c|c|c|}
\hline \multirow[b]{2}{*}{ Cultivars } & \multicolumn{4}{|c|}{2016} & \multicolumn{4}{|c|}{2017} \\
\hline & 0. day & $\begin{array}{l}\text { 15. day } \\
\text { control }\end{array}$ & $\begin{array}{l}\text { 15. day } \\
\text { drought }\end{array}$ & $\begin{array}{l}\text { 7. day } \\
\text { recovery }\end{array}$ & 0. day & $\begin{array}{l}\text { 15. day } \\
\text { control }\end{array}$ & $\begin{array}{l}\text { 15. day } \\
\text { drought }\end{array}$ & $\begin{array}{l}\text { 7. day } \\
\text { recovery }\end{array}$ \\
\hline Doruk77 & $55.06 \mathrm{bc}$ & $58.65 \mathrm{a}$ & $53.87 \mathrm{~b}$ & $55.38 \mathrm{bc}$ & $55.00 \mathrm{~cd}$ & $56.31 \mathrm{bc}$ & $52.94 \mathrm{bc}$ & $54.85 \mathrm{bc}$ \\
\hline Dorukhan77 & $55.73 \mathrm{abc}$ & $54.65 \mathrm{bc}$ & $54.88 \mathrm{ab}$ & $55.94 \mathrm{abc}$ & $54.58 \mathrm{~cd}$ & $54.23 \mathrm{c}$ & $52.77 \mathrm{bc}$ & $54.49 \mathrm{bc}$ \\
\hline Hilal77 & $53.36 \mathrm{c}$ & $55.32 \mathrm{bc}$ & $53.16 \mathrm{~b}$ & $53.44 \mathrm{c}$ & $55.03 \mathrm{bcd}$ & $56.85 \mathrm{ab}$ & $50.55 \mathrm{c}$ & $54.43 \mathrm{bc}$ \\
\hline Bolverim77 & $56.03 \mathrm{ab}$ & $55.52 \mathrm{bc}$ & $54.71 \mathrm{ab}$ & $56.16 \mathrm{ab}$ & $56.93 \mathrm{abc}$ & $55.36 \mathrm{bc}$ & $55.96 \mathrm{a}$ & $56.71 \mathrm{ab}$ \\
\hline Eren77 & $57.93 \mathrm{a}$ & $57.62 \mathrm{a}$ & $56.53 \mathrm{a}$ & $58.02 \mathrm{a}$ & $58.22 \mathrm{a}$ & $58.63 \mathrm{a}$ & $56.07 \mathrm{a}$ & $57.90 \mathrm{a}$ \\
\hline Erenoğlu77 & $56.80 \mathrm{ab}$ & $56.89 \mathrm{ab}$ & $55.32 \mathrm{ab}$ & $56.79 \mathrm{ab}$ & $57.43 \mathrm{ab}$ & $58.41 \mathrm{a}$ & $55.01 \mathrm{ab}$ & $57.18 \mathrm{a}$ \\
\hline Ata77 & $54.70 \mathrm{bc}$ & $54.20 \mathrm{c}$ & $53.11 \mathrm{~b}$ & $54.53 \mathrm{bc}$ & $54.18 \mathrm{~d}$ & $55.36 \mathrm{bc}$ & $53.54 \mathrm{ab}$ & $54.28 \mathrm{c}$ \\
\hline LSD & 3.55 & 3.02 & 3.40 & 3.56 & 3.40 & 2.68 & 3.61 & 3.23 \\
\hline
\end{tabular}

*: There is no difference between the averages shown with the same letter in the same column

\section{Discussion}

Drought; It occurs when the usable water in the soil decreases in plants and water is lost by transpiration or evaporation due to atmospheric conditions (Jaleel et al., 2009). Drought stress is one of the most important stresses affecting plant growth and yield, and it affects many physiological, biochemical and molecular properties in plants (Özfidan, 2010). Therefore, understanding the physiological and biochemical responses of plants in resistance to drought stress will be useful in identifying species and varieties that are resistant to drought conditions. In this context, in our study on newly bred strawberry cultivars, it was determined that the responses of cultivars to drought stress differ. During the 15 days of drought stress, the leaf area of the plants hardly increased. Reduction in leaf area due to drought also reduces dry matter production as it reduces plant fresh weight and photosynthesis activity due to sunlight intake (Sayyari and Ghanbari, 2012). In addition, dry matter accumulation in drought-stressed plants may result from changes in carbon and nitrogen metabolism as a result of aging and dying of leaves (Bertamini et al., 2006). Many plants provide resistance to dry conditions by accelerating the aging and shedding of their old leaves. This process is known as very period. Although the SPAD values of the cultivars are very close to each other, the highest values were determined in Eren77 cultivar in all periods (Table 9). and Dorukhan77 cultivars compared to other cultivars. wever, during the recovery period, the stomatal rol level. The results of 2017 are largely similar to the results of 2016 (Table 8). "leaf area arrangement" (Mahajan and Tuteja, 2005). In studies on the subject, Nigues and Baker (2000), olive, lavender and rosemary; Boutraa et al., (2010) in wheat; İpek (2015) on Myrobolan and Garnem rootstocks; Klamkowski and Treder (2008) determined that the leaf area decreased with drought stress in strawberry. The decrease in leaf area in the plant under drought stress is associated with the slowdown of photosynthesis. This slowdown in photosynthesis is due to chlorophyll content, water intake and insufficient nitrogen content. Nair et al., (2009) found a decrease in leaf area, water use efficiency, net assimilation rate and transpiration rate in okra with drought stress.

It was determined that plant fresh and dry weights of strawberry plants decreased under drought stress, while there was a slight increase in root fresh and dry weights. Leaf growth is more susceptible to drought stress than root development. The reduction in leaf expansion is beneficial for plants in water-deficient conditions. Because the decrease in the growth of leaf area increases the root development and volume by carrying the excess of energy and carbohydrates required for growth to the roots (Taiz and Zeiger, 2008). While water stress causes a decrease in growth due to the inability to supply the water required for cell divi- 
sion and growth, deficiencies in carbon and nitrogen metabolism also cause decreases in the fresh and dry weights of plants (Kluge, 1976; Bertamini et al., 2006). Our results, Rahman et al., (2002) tomato, Sivritepe et al., (2008) Gisela 5 cherry rootstock, Abbaspour et al., (2012) Pistachio, Karimi et al., (2012) on almond, Bolat et al., (2014) on apple and pear, and İpek (2015) on Myrobolan and Garnem rootstocks.

The maintenance of cell structure under stress conditions depends on the properties of membrane proteins and the structure of lipid compounds. Oxidative stress usually causes cell damage due to the deterioration in the structure of membrane proteins and lipids, depending on the concentration of active oxygen derivatives. For this reason, cell damage occurs at lower levels in genotypes that operate enzyme activities or perform osmotic regulation (Kuşvuran, 2010). In our study, drought stress caused significant increases in cell membrane permeability. These results are similar to the data obtained by Karimi et al., (2012) on 5 almond cultivars and GF 677 rootstock, Patel et al., (2011) on chickpea and İpek (2015) on Myrobolan and Garnem rootstocks in vitro conditions.

Decreased root activities in plants in arid conditions, resulting in the roots not getting enough water, decreases the water content of the leaves (Taiz and Zeiger, 2008). The water content of plants provides the protection of turgor and the uptake of mineral substances from the soil. When the relative water content decreases, the plant cells shrink by losing their turgor and try to control the preservation of cell volume by activating the protective mechanisms of the osmotic balance (Çirak and Esendal, 2006). In our study, it was determined that drought application decreased YOSI values and stomatal conductivity. Similar results were obtained in studies on the subject. Rahman et al., (2002) determined that there was a decrease in the relative water content of the leaves when the duration of water stress was prolonged in 2 tomato cultivars. Larbi and Mekliche (2004) determined that the relative water content of leaves decreased in two wheat cultivars under drought conditions. Ghaderi and Siosemardeh (2011) examined the effects of different irrigation regimes on two strawberry cultivars and found the highest leaf proportional water content in the control group.

In our study, some decreases were observed in chlorophyll content under drought stress in all cultivars. Water is one of the most important substances for chlorophyll synthesis, leaf water content must be high to maintain the maximum amount of chlorophyll (Goss, 1973). Efeoğlu (2009) determined in his study that the total amount of chlorophyll in the leaves of the corn plant under drought stress decreased, and the amount of chlorophyll increased with re-irrigation. Chlorophyll is one of the main pigments in the plant and a decrease in its concentration causes chlorosis, a decrease in growth and yield. Plants under stress give similar responses in terms of chlorophyll breakdown. Alisadeh et al. (2011) found that in apples and Zanjani et al (2012) in zucchini there was a decrease in the amount of chlorophyll with drought stress.

In the research that lasted for two years, the results related to the properties examined in general showed parallel. Differences between years in terms of some characteristics may be the result of climatic differences between years in uncontrolled greenhouse conditions.

\section{Conclusions}

Factors that inhibit plant growth are called stress. Stress caused by drought, salinity, high and low temperatures, and heavy metals are common in many agricultural parts of the world. In recent years, with the effect of global warming, the importance of water has started to be felt more and more with agricultural drought. Plants develop tolerance mechanisms to adapt to environmental conditions in the nature of physiological, biochemical and molecular responses to drought stress (İpek, 2105). All strawberry cultivars used in our study were affected by drought, but some cultivars were less affected than others. Doruk77 and Dorukhan77 cultivars were found to be superior to other cultivars in terms of both drought resistance and post-drought recovery. The high drought tolerance of these cultivars may depend on genetic characteristics. As a matter of fact, the parents of both varieties are the same (Tufts X Cruz). With the application of drought, leaf growth, decrease in LRWC and SPAD values in varieties; Membrane permeability and stomatal conductivity increased.

\section{References}

Abbaspour H, Saeidi-Sar S, Afshari H, Abdel-Wahhab MA (2012). Tolerance of mycorrhiza infected pistachio (Pistacia vera L.) seedling to drought stress under glasshouse conditions. Journal of Plant Physiology 169: 704 -709.

Alizadeh A, Alizade V, Nassery L, Eivazi A (2011). Effect of drought stress on apple dwarf rootstocks. Technical Journal of Engineering and Applied Science 1: 86-94.

Anonim (2008). İklim değişikliği ve yapılan çalışmalar. T.C. Çevre ve Orman Bakanlığı Yayınları.

Anonymous (2017). https://arastirma. tarim.gov.tr /yalovabahce/Menu/34/Meyveler, Date of access: 19.06.2021.

Anonymous (2021). https://fao.org. Date of access : 19.06.2021

Ashraf M, Foolad MR (2007). Roles of glycine betaine ve proline in improving plant abiotic stress resistance. Envionmental ve Experimental Botany 59: 206-216.

Bertamini M, Zulini L, Muthuchelian K, Nedunchezhian N (2006). Effect of water deficit on photosynthetic and other physiological responses in grapevine (Vitis vinifera L. cv. Riesling) plants. Photosynthetica 44: 151-154.

Bolat I, Dikilitas M, Ercisli S, Ikinci A, Tonkaz T (2014). The effect of water stress on some morphological, physiological, and biochemical characteristics and bud success on apple and quince rootstocks. The Scientific World Journal, 1-8.

Boutraa T, Akhkha A, Abdulkhaliq AS, Alhejeli AM (2010). Effect of water stress on growth and water use efficiency 
(WUE) of some wheat cultivars (Triticum durum) grown in Saudi Arabia. Journal of Taibah University of Science 3: 39-48.

Caruso A, Chefdor F, Carpin S, Depierreux C, Delmotte FM, Kahlem G (2008). Physiological characterization and identification of genes differentially expressed in response to drought induced by PEG 6000 in Populus canadensis leaves. Journal of Plant Physiology 165: 932-941.

Çırak A, Esendal E (2006). Soyada kuraklık stresi, OMÜ Ziraat Fakültesi Dergisi, 21: 231-237.

Demirtaş, MN, Kırnak H (2009). Kayısıda farklı sulama yöntemleri ve aralıklarının fizyolojik parametrelere etkisi. Yüzüncü Y1l Üniversitesi Tarım Bilimleri Dergisi 19: 7983.

Deuel CL, Plotto A (2004). Strawberries and raspberries. In Processing Fruits. www.scribd.com. Date of access: 10.11.2013.

Efeoğlu N (2009). Studies on the changes in lipid peroxidation and antioxidants in drought stress induced cowpea (Vigna unguiculata L.) varieties, Journal of Environmental Biology 29: 689-691.

Ghaderi N, Siosemardeh A (2011). Response to drought stress of two strawberry cultivars Horticulture, Environment and Biotechnology 52: 6-12.

Goss JA (1973). Physiology of plants and their cells. Bergamon Press Inc. Maxwell House, Fairview Park Elmsford N.Y.10523, P:135

İpek M, Pirlak L, Esitken A, Dönmez MF, Turan M, Sahin F (2014). Plant growth-promoting rhizobacteria (PGPR) increase yield, growth and nutrition of strawberry under high-calcareous soil conditions. Journal of Plant Nutrition 37: 990-1001.

İpek M (2015). Determination of Garnem and Myrobolan 29c rootstocks reactions against drought stress in vitro conditions. PhD Thesis, Selçuk University (Unpublished), Konya, Turkey.

Jaleel CA, Manivannan P, Wahid A, Farooq M, Somasundaram R, Panneerselvam R (2009). Drought stress in plants: a review on morphological characteristics and pigments composition. International Journal of Agricultural Biology 11: 100-105.

Karimi S, Yadollahi A, Nazari-Moghadam R, Imani A, Arzani K (2012). In vitro screening of almond (Prunus dulcis (Mill.)) genotypes for drought tolerance. Journal of Biolological and Environmental Science 6: 263-270.

Khan Q, Ahmad A (2004). Salt tolerance of cotton cultivars in relation to relative growth rate in saline environments. Inernational Journal of Agriculture \& Biology 6: 786787.

Klamkowski K, Treder W (2008). Response to drought stress of three strawberry cultivars grown under greenhouse conditions. Journal of Fruit and Ornamental Plant Research 16: 179-188.

Kluge M (1976). Carbon and nitrogen metabolism under water stress: Water and Plant Life 243-252.

Kuşcu A (2006). Yazlık ekmeklik buğday (Triticum aestivum L.) veriminde son çeyrek yüzyılda gerçekleşen ilerlemelerin morfolojik ve fizyolojik esasları, Doktora Tezi, Çukurova Üniversitesi Fen Bilimleri Enstitüsü (Basılmamış), Adana.

Kuşvuran Ş (2010). Kavunlarda kuraklık ve tuzluluğa toleransın fizyolojik mekanizmaları arasındaki bağlantılar.
Doktora Tezi, Çukurova Üniversitesi Fen Bilimleri Enstitüsü (Basılmamış), Adana.

Lutts K, Bouharmont C (1996). NaCl-induced senescence in leaves of rice (Oryza sativa L.) cultivars differing in salinity resistance. Annals of Botany 78: 389-398.

Mahajan S, Tuteja N (2005). Cold, salinity and drought stresses: An overview. Archives of Biochemistry and Biophysics 444: 139-158.

Monti LM (1987). Breeding plants for drought resistance; the problem and its relevance, drought resistance in plants. Meeting Held in Amalfi, Belgium, 1-8.

Nair AS, Abraham TK, Jaya DS (2008). Studies on the changes in lipid peroxidation and antioxidants in drought stress induced cowpea (Vigna unguiculata L.) varieties. Journal of Environmental Biology 29: 689-691.

Nogués S, Baker NR (2000). Effects of drought on photosynthesis in Mediterranean plants grown under enhanced UV-B radiation. Journal of Experimental Botany 51: 1309-1317.

Özcan M, Babaoğlu M, Gürel E (2004). Bitki biyoteknolojisi genetik mühendisliği ve uygulamaları. Selçuk Üniversitesi Vakfı Yayınları, Konya.

Özfidan C (2010). Ekzojen ABA uygulamasının kuraklık stresi (PEG-6000) altındaki yabani ve ABA-eksik Arabidopsis mutantları üzerindeki biyokimyasal ve fizyolojik etkilerinin araştırılması. Doktora Tezi, Ege Üniversitesi Fen Bilimleri Enstitüsü (Basılmamış), İzmir.

Patel PK, Hemantaranjan A, Sarma BK, Singh R (2011). Growth and antioxidant system under drought stress in chickpea (Cicer arietinum L.) as sustained by salicylic acid. Journal of Stress Physiology \& Biochemistry 7: 130-144.

Rahman SML, Mackay AW, Quebedeaux B, Nawata E, Sakuratani T, Mesbahuddin ASM (2002). Superoxide dismutase activity, leaf water potential, relative water content, growth and yield of a drought-tolerant and a drought-sensitive tomato (Lycopersicon esculentum Mill.) cultivars. Subtropical Plant Science 54: 16-22.

Romo S, Labrador E, Dopico B (2001). Water stressregulated gene expression in Cicer arietinum seedlings and plants. Plant Physiolology and Biochemistry 39: 1017-1026.

Sayyari M, Ghanbari F (2012). Effects of super absorbent polymer a 200 on the growth, yield and some physiological responses in sweet pepper (Capsicum annuum L.) under various irrigation regimes. International Journal of Agricultural and Food Research 1: 1-11.

Sircelj H, Tausz M, Grill D, Batic F (2007). Detecting different levels of drought stress in apple trees (Malus domestica Borkh.) with selected biochemical and physiological parameters. Scientia Horticulturae 113: 362-369.

Sivritepe N, Erturk U, Yerlikaya C, Turkan I, Bor M, Ozdemir F (2008). Response of the cherry rootstock to water stress induced in vitro. Biologia Plantarum 52: 573-576.

Taiz L, Zeiger E (2008). Bitki fizyolojisi, Palme Yayımcılık, Ankara, 547.

Zanjani KE, Rad AHS, Naeemi M, Aghdam AM, Taherkhani $T$ (2012). Effects of zeolite and selenium application on some physiological traits and oil 126 yi eld of medicinal pumpkin (Cucurbita pepo L.) under drought stress. Current Research Journal of Biological Sciences 4: 462-470 